\title{
A Review of A New Literacies Sampler
}

Val Mulholland

University of Regina

Abstract

A book review of Knobel's and Lankshear's (2007), A New Literacies Sampler. New York: Peter Lang. ISBN 978-0-8204-9523-1 


\section{A Review of A New Literacies Sampler}

On virtually every visit I have made to high schools of late, I have been reminded of how permeable technology has made classroom walls. I'll be specific. Recently, I was seated in a Grade 11 classroom waiting for an intern to begin teaching the class when a student announced that her pet rat had escaped. Amid the ensuing uproar, two other students seated near me had time to discuss their friend's recent piercing. "She got her tragus done for her $16^{\text {th }}$ birthday," said one casually to the other. "What's that?" "I'll show you." In a matter of seconds, the first student had an illustrated image of the human ear displayed on one of the new Mac computers installed along the periphery of the classroom. The two students investigated the site, read with interest all of the available information about the ear, and then they surfed to a Youtube site to watch a girl, roughly the age of their friend, having her tragus pierced. In the meantime, the rat was discovered cowering behind a backpack, the intern and the classroom teacher reiterated that pets were not welcomed in class, and order was restored. I resumed my job of taking notes, equipped with fresh knowledge about the parts of the human ear. The two students I had overheard remained intent on their own digital discoveries until their teacher noticed and they were asked to shut it down.

The opening vignette provides the real life context for my reading of Michele Knobel's and Colin Lankshear's newest edited book, A New Literacies Sampler which continues their work in digital literacies, new technologies and social practices, and particularly research of these emerging, swiftly evolving literacies. As general editors of the Peter Lang series New Literacies and Digital Epistemologies, they are particularly well-qualified to fulfill their stated dual purposes of sampling both typical forms of new literacies of interest to scholars, and methodologies useful to researchers in these fields. The collection opens and closes with chapters by the editors, which serve to frame the survey of studies that comprise the intervening seven chapters. The authors include James Gee, Angela Thomas, Julia Davies and Guy Merchant, Jennifer Stone, Kevin Leader, and Jessica Hammer-all well-known authors in the field. It is worth a few hours to google each one to read their individual websites. The topics covered include fanfiction, academic blogging, memes, English language learning, and student use of technology inside and outside of a girls' school. As a long-time reader of James Paul Gee, I was particularly interested in his chapter on pleasure, gaming, and the projective stance. A coda by Cynthia Lewis provides a second reading of the contents, useful for any reader who may harbor misgivings about the field of new literacies, or who may persist in believing new tools are only that, new tools, not new ways of knowing, doing, and being.

For the visually or technologically literate, the cover serves as a summary of what is to follow. Within the framed picture on the cover are nine separate images ranging from the anime figure at the centre, to an iPod, a webpage, and a young man sitting cross-legged, completely absorbed by his laptop's screen. A single green die stands for all the forms of gaming prevalent in the digital world. Each image represents the contents of each chapter in the book. As a reader with knowledge of needlework knows, the scale of the specific images is of little consequence just as scale was askew in traditional samplers. The use of a sampler as an image on the cover and as a word in the title works to create cleverly a bridge between past and present interests in literacy research.

The font used in the title references the stitched samplers that were created historically by refined young women eager to display their needlework skills. At one time, acquisition of such skill was a marker of social class, modesty, and virtue. The use of samplers as a trope raises 
questions that are pertinent to the ethos issues raised by the editors in Chapter 1 . Are samplers a symbol of the leisure time of the privileged or a symbol of gendered domestic drudgery? Are samplers an art form or a humble craft? Is the cover art of The New Literacies Sampler a bricolage or a random pastiche? Depending on the reader's perspective, a variety of responses to these questions make sense. For some, new literacies are evidence of a social hierarchy that privileges the affluent classes who can afford technology. For some, new literacies are perceived as a White, male preoccupation. The women authors dispel and respond to some of these questions.

Sampler also references the contemporary use of the word. Sampling alludes to the practice of hip-hop artists who borrow riffs from other artists to create new music, which speaks to the democratic, open-access to intellectual property ethos that the new literacies represent. Are the new literacies the domain of the privileged who are early adopters of new technology? Or does hiphop culture more accurately represent new literacies? Are students expected to be consumers or producers of media or both? Is this a commercial enterprise, part of new capitalism, or an inherently democratic process? All the questions are raised on the cover and are addressed to various degrees within the studies included in the text. A recent New Yorker cartoon featured a teacher admonishing a student for "sampling" on a homework assignment, suggesting to me that new literacies are mainstream.

Cherland and Harper (2007) use the term multiliteracies to describe the content of A New Literacies Sampler; they write that it "calls for the teaching of a variety of text forms associated with a range of technologies, so that all students gain competent control of many representational forms” (p.131). They stress that literacies are connected to the secondary discourses of students' lives, implying that a critical stance is inherent in the move toward new literacies. Knobel and Lankshear use a sociocultural approach to define new literacies, which they suggest possess both new "technical stuff" and new "ethos stuff." They make a distinction between a first mindset that considers digital technology as simply a way to do what we have previously done (look up information; compose a traditional essay; give an oral report to class), as opposed to the second mindset that employs technology for "different kinds of values, emphases, priorities, perspectives, orientations, and sensibilities... from those established during the era of print and analogue forms of representation” (p. 9). In their view,

[The more a teacher's literacy practice] privileges participation over publishing, distributed expertise over centralized expertise, collective intelligence over individual possessive intelligence, collaboration over individuated authorship, dispersion over scarcity, sharing over ownership, experimentation over "normalization,” innovation and evolution over stability and fixity, creative-innovative rule breaking over generic purity and policing, relationship over information broadcast, and so on, the more we regard it as a new "literacy." (p.21)

The ways of doing and having literacy reported in this collection represent an elemental shift from the ways schools have traditionally organized and conceived literacy instruction. The editors and authors support the idea that if we accept that we use tools best suited to a student's need and right to learn, we must resist privileging pens, paper, and familiar texts in instructional practice.

To return to the students concerned with tragus piercing at the beginning, I neglected to mention that these students were enrolled in a program designed to keep them in school. Some 
educators might label the students "at-risk." What was clear to me on the day that I had cause to observe them at work in new literacies is that they had easy access to information that was not restricted to printed-text or authorized curriculum. They were confident and competent in their use of technology and language. Their competencies may not have been valued regularly in school, but outside of school, they were connected.

At the time of conventional publication, The New Literacies Sampler was made available online. Consequently, my copy is riddled with scribbling, highlighting, and sticky notes. I knew that if I wore out the pages, I could print a new copy or search it as I pleased. Check it out for yourself, at the library or online. 


\section{Reference}

Cherland, M. R., \& Harper, H. (2007). Advocacy research in literacy education: Seeking higher ground. Mahwah, NJ: Lawrence Erlbaum. 